\title{
CURCUMA XANTHORRHIZA ROXB. (PEMANFAATAN DAN BIOAKTIVITASNYA)
}

\author{
Marina Silalahi \\ marina_biouki@yahoo.com \\ Prodi Pendidikan Biologi FKIP, Universitas Kristen Indonesia, Jakarta.
}

\begin{abstract}
Curcuma xanthorrhiza Roxb have been long time used by human as medicine and spices. This article aims to explain the uses and biological activitie of Curcuma xanthorrhiza. This paper is based on literature offline and online media. Off line literatures based on handbooks, dissertations and thesis. Web, Scopus, Pubmed, Journal, and other online media to supplement used in this article. Curcuma xanthorrhiza have been used as medicine for various purposes such as ulcer, stomachache, malnutrtions, diabetes mellitus. Curcuma xanthorrhiza have bioactivites as anti-inflammatory, wound, cholesterol, anti carsinogenic, antioxidant, anti diabetic, antibacterial, antifungal, phytoestrogenic, and neuroprotective.
\end{abstract}

Keywords: Curcuma xanthorrhiza, antimicrobaa, antioxidant, diabetes mellitus

\begin{abstract}
ABSTRAK
Curcuma xanthorrhiza Roxb telah lama digunakan manusia sebagai obat maupun bumbu masak. Artikel ini bertujuan untuk menjelaskan menfaat dan bioaktivitas dari Curcuma xanthorrhiza. Penulisan artikel ini didasarkan atas kajian literatur online maupun offline. Data offline berupa buku, jurnal, tesis maupun tulisan ilmiah lainnya. Sumber online berupa Web, Scopus, Pubmed, Jurnal, dan artikel ilmiah lainnya. Curcuma xanthorrhiza digunakan sebagai obat untuk mengatasi penyakit ulcer, sakit perut, diabetes mellitus. Berdasarkan kajian bioactivitasnya, Curcuma xanthorrhiza bersifat sebagai anti-inflammatory, obat luka, kolesterol, anti kanker, antioksidan, anti diabetik, anti bakteria, anti jamur, phytoestrogenic, dan neuroprotective.
\end{abstract}

Kata kunci: Curcuma xanthorrhiza, antimikroba, antioksidan, diabetes mellitus

\section{PENDAHULUAN}

Zingiberaceae atau yang dikenal dengan empon-emponan merupakan salah satu famili dari ordo Zingoberales, yang banyak digunakan sebagai bumbu masak maupun sebagai obat tradisional, khususnya bagi masyarakat lokal Indonesia. Zingiberaceae memiliki sekitar 50 genus (Saensouk et al. 2015), dan salah satu genusnya adalah Curcuma. Genus Curcuma tercatat sedikitnya 60 spesies di dunia (Larsen dan Larsen 2006), yang diciri dengan adanya curcumin pada bagian rhizomanya. Walaupun setiap spesies pada genus Curcuma memiliki curcumin, namun kandungan senyawa metabolit 
sekunder lainnya bervariasi antar spesies Sebagai contoh, xanthorihol pada Curcuma xanthorrhiza (Jantan et al. 2012), ar-tumeron pada Curcuma longa (Araujo dan Leon 2001).

Curcuma xanthorrhiza yang dikenal juga sebagai temulawak atau Javanese tumeric banyak dimanfaatkan sebagai obat, baik sebagai bahan utama maupun sebagai bahan tambahan. Javanese tumeric secara harfiah memiliki arti "kunyit Jawa" (kunyit yang berasal dari Pulau Jawa). Dilihat dari sturktur morfologi daun maupun rhizomanya temulawak (Curcuma xanthorrhiza) memiliki kesamaan dengan kunyit (Curcuma longa), namun ukuran rhizoma dan daunnya lebih besar, sehingga oleh etnis Sunda sering juga disebut koneng gede ("kunyit besar") (de Padua et al. 1999), namun warna rhizoma Curcuma xanthorrhiza lebih tua dibandingkan dengan Curcuma longa. Berbeda halnya dengan Curcuma longa, yang oleh masyarakat lokal Indonesia banyak digunakan sebagai bumbu masak, namun Curcuma xanthorrhiza lebih dikenal sebagai bahan obat, khususnya jamu (obat tradisional etnis Jawa khusunya daerah Jawa Tengah dan Yogjakarta). Curcuma xanthorrhiza sangat mudah ditemukan diberbagai daerah di
Indonesia seperti Sumatra dan pulau Jawa. Struktur daun dan bunga yang menarik menjadikan temulawak juga mudah ditemukan di pekarangan yang berfungsi juga sebagai tanaman hias (Gambar 1).

Sebagai obat tradisional Curcuma xanthorrhiza dimanfaatkan untuk berbagai tujuan seperti obat maag, sakit perut, kurang giji, diabetes mellitus (Silalahi et al. 2015a; Silalahi et al. 2015b). Munin dan Hanani (2012) menyatakan bahwa pemanfaatan tumbuhan sebagai obat berhubungan dengan kandungan metabolit sekundernya atau yang dikenal juga sebagai senyawa bioaktif. Jenis dan konsentrasi/kadar senyawa bioaktif di dalam tumbuhan bervariasi tergantung tahap perkembangan, lingkungan, dan faktor genetik (Taiz dan Zeiger 2006). Walaupun Curcuma xanthorrhiza telah lama dimanfaatkan sebagai obat, namun tulisan secara konprehensip mengenai hubungan pemanfaatan dan senyawa bioaktifnya masih terbatas. Artikel ini diharapkan akan menjadi salah satu sumber informasi yang menjelaskan hubungan kandungan metabolit sekunder Curcuma xanthorrhiza dangan bioaktivitasnya sehingga pemanfaatannya dapat dioptimalkan untuk meningkatkan kesehatan 
masyarakat maupun sebagai obat tradisional.

\section{METODE}

Tulisan ini didasarkan pada kajian literatur baik secara online dan offline. Offline didasarkan pada berbagai buku literatur seperti Plants Resources of South East Asian dan buku lainnya. Media online didasarkan pada Web, Scopus, Pubmed, dan media on-line yang digunakan untuk publikasi dari berbagai Scientific journals.

\section{PEMBAHASAN}

\section{BOTANI Curcuma xanthorrhiza} Roxb.

Curcuma merupakan salah satu genus dari famili Zingiberaceae yang terdistribusi luas di daerah tropis maupun sub tropis terutama di India, Thailand, Indochina, Australia bagian Utara, dan telah banyak dibudidayakan sebagai bahan pangan maupun sebagai obat (Burkil 1965). Genus Curcuma beranggotakan sekitar 60 spesies (Larsen dan Larsen 2006) - 70 spesies (Lawrence 1951) bahkan 80 spesies (Sirirugsa et al. 2007). Curcuma xanthorrhiza memiliki vernacular name antara lain: temulawak (Indonesia, Madura), koneng gede (Sunda), Javanese tumeric (Inggris), dan temu lawas (Malaysia). Temulawak merupakan tumbuhan native di pulau Jawa, Madura dan Maluku (de Padua et al. 1999) dan telah banyak di budidayakan di Indonesia, Malaysia, Thailand, Philipina dan India.

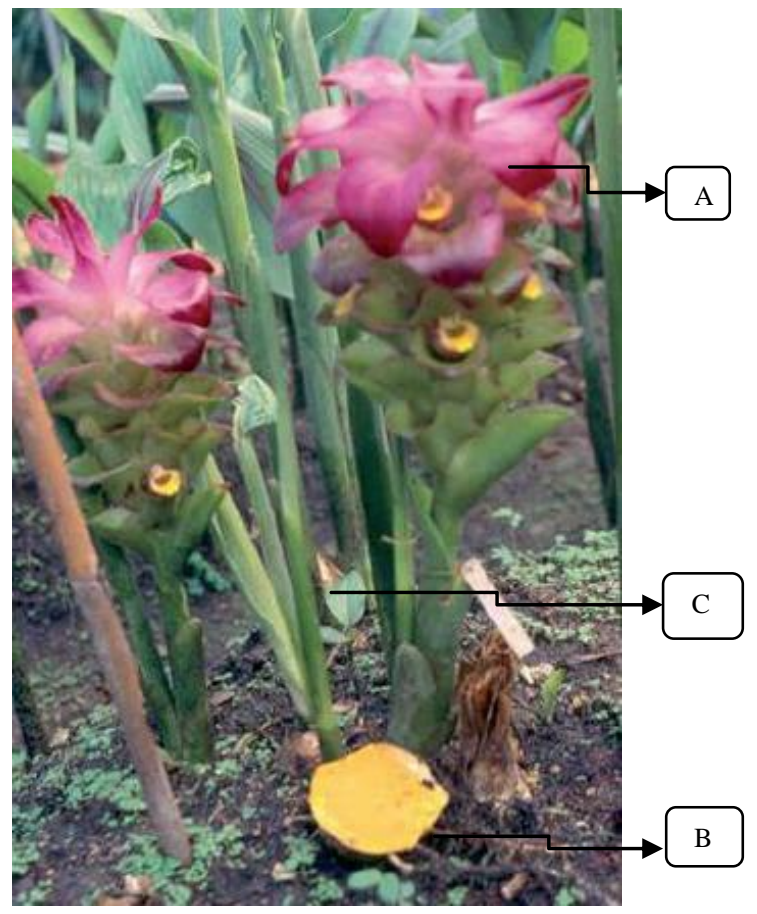

Gambar 1.

Curcuma
Rhizoma, C. Habitus (Srigusa et al. 2007)

Curcuma zanthorrhiza, pertama kali diperkenalkan oleh Roxburgh yang diperoleh dari Maluku. Rhizomanya besar dengan bewarna kuning gelap atau kuning-orange di bagian dalam rhizomanya sedangkan di bagian dalam memiliki warna orange hingga orange-merah. (Srigusa et al. 2007). Temulawak telah lama dimanfaatkan oleh masyarakat Indonesia maupun 
Malaysia dan di India telah dimanfaatkan lebih dari 100 tahun yang lalu (Skornickov dan Sabu 2005). Daunnya merupakan daun lengkap dengan panjang pelepah hingga 75 $\mathrm{cm}$, helaian daun berbentuk elipsoblong atau olong-lanset. Helaian daun memiliki ukuran 25-100 cm x 8$20 \mathrm{~cm}$ bewarna hijau dengan warna kemerahan-coklat berbentuk pita dekat tulang daun utama. Bunga majemuk dengan braktea bewarna hijau pucat, corolla bewarna bewarna merah muda dengan labellum berukuran 2-2,5 cm x 1,5-2,0 cm bewarna kekuningan dengan warna orange berbentuk pita diagian tengah (Gambar 1). Tumbuh dengan baik pada tanah yang lembab dengan ketinggian hingga mencapai 750 m dpl (de Padua et al. 1999; Skornickov dan Sabu 2005).

\section{Metabolit Sekunder}

Tumbuhan menghasilkan berbagai jenis metabolit sekunder melalui proses metabolime sekunder. Setiap spesies tumbuhan memiliki jenis metabolit sekunder yang relatif berbeda antara satu spesies dengan spesies yang lainnya. Dalam spesies yang sama, jenis maupun konsentrasi metabolit sekunder setiap individu relatif berbeda, dipengaruhi oleh berbagai faktor seperti, lingkungan, tahap pertumbuhan, jenis organ, genetik, dan serangan patogen (Taiz dan Zeiger 2005). Sebagai contoh Catharanthus roseus mengakumulasi ajmalisin pada bagian akar, sedangkan cataranthin pada bagian daun (Joy et al. 1998). Antosianin pada tumbuhan diproduksi lebih banyak pada saat terjadi pembungaan, dibandingkan dengan tahapan lainnya.

Metabolit sekunder yang terdapat pada tumbuhan, fungsinya berhubungan dengan pertahanan terhadap serangan patogen (mikroba) maupun adaptasi terhadap lingkungan yang kurang menguntungkan. Sifat metabolit tersebut diadopsi oleh manusia dan kemudian dikembangkan sebagai bahan obat. Silalahi (2017) menyatakan bahwa bunga Etlingera elatior memiliki jenis essensial oil pada bunga lebih banyak dibandingkan buah, batang, dan daun. Perbedaan kandungan metabolit sekunder pada setiap organ mengakibatkan perbedaan pemanfaatannya. Sebagai contoh rhizoma Curcuma longa dimanfaatkan sebagai obat diare, sedangkan daunnya sebagai bahan sauna tradisional (Silalahi 2014).

Metabolit sekunder pada tumbuhan sebagian besar disintesis dari senyawa antara dari proses metabolisme primer. Perbedaan jalur 
metabolisme dan prekusornya senyawa seskuiterpenoid (Duke 2003). mengakibatkan produk akhir yang Tabel 1. menunjukkan jenis dan dibentuk (Taiz dan Zeiger 2006). struktur metabolit sekunder pada Biosintesis metabolit sekunder pada Curcuma xanthorrhiza. Xanthorrhizol tumbuhan memiliki empat prekursor utama yaitu eritrosa-4-fosfat, fosfoenolpiruvat, piruvat, dan 3fosfogliserat (Taiz dan Zeiger 2006). Masing-masing prekursor kemudian akan membentuk jalur biosintesis kelompok senyawa metabolit sekunder.

Zingiberaceae dilaporkan memiliki senyawa utama yang disebut dengan zingiberene, dari kelompok merupakan senyawa sesquiterpene dengan berat molekul 218 (Lee et al. 2008). Rhizoma Curcuma xanthorrhiza mengandung senyawa utama xanthorrhizol dengan konsentrasi mencapai 64,38\% (Helen et al., 2012), walaupun demikian kadar xanthorrhizol yang diperoleh dari rhizoma Curcuma xanthorrhiza dipengaruhi oleh zat yang digunakan dalam ekstraksi.

Tabel 1. Struktur dari senyawa utama dari Curcuma xanthorrhiza (Jantan et al. 2012).

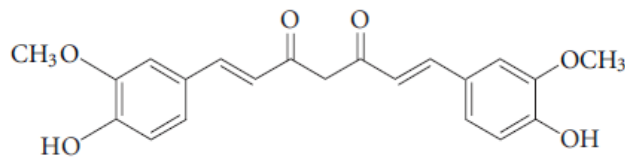

Curcumin<smiles>O=C(/C=C/c1ccc(O)cc1)CC(=O)/C=C/c1ccc(O)cc1</smiles>

Bisdemethoxycurcumin

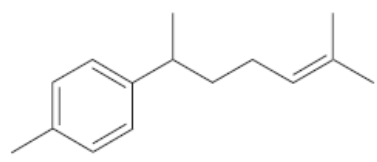

Ar-Curcumene

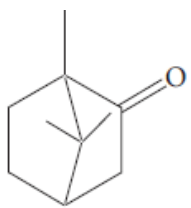

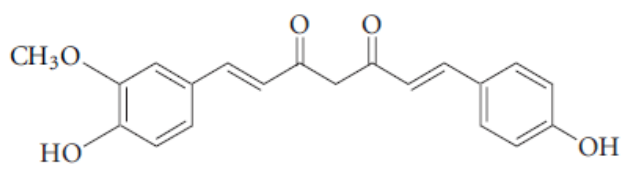

Demethoxycurcumin<smiles>CC(C)=CCCC(C)c1ccc(C)c(O)c1</smiles>

Xanthorrhizol<smiles>C=C(C)CCCC(C)C1=CCC(C)=CC1</smiles>

$\beta$-Curcumene

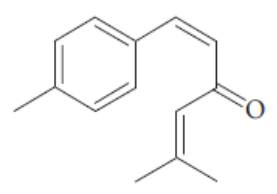




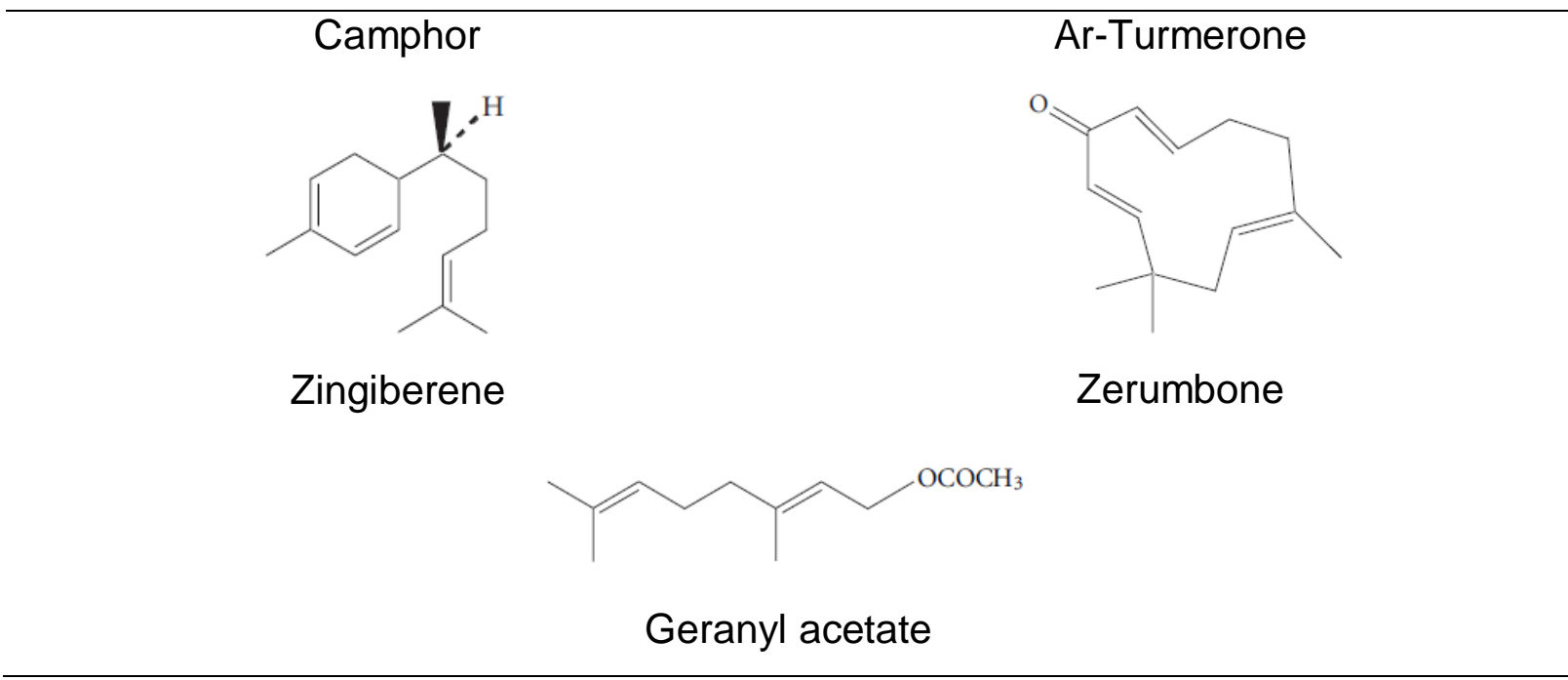

\begin{abstract}
Curcuma
xanthorrhiza

mengandung berbagai senyawa bioaktif seperti xanthorrhizol, curcumin, dan senyawa yang mudah menguap atau sering juga dikenal dengan volatil subtances (Devaraj et al. 2010). Xanthorrhizol merupakan suatu senyawa seskuiterpenoid golongan bisabolen (bisabolane-type sesquiterpenoid) (Devaraj et al. 2010). Rhizoma Curcuma xanthorrhiza juga mengandung gula, saponins,
\end{abstract} flavonoids, glikosida jantung (cardiac glycosides), terpenoids, anthraquinones dan tidak memiliki alkaloids, steroids, tannins, dan phlobatannin (Devaraj et al. 2010). Xanthorrhizol merupakan senyawa sesquiterpene dengan berat molekul 218 (Lee et al. 2008; Mangunwardoyo et al. 2012; Lee et al. 2008).

Rhizoma Curcuma xanthorrhiza disamping kaya akan sesquiterpenes (seperti xanthorrizol, bisacumol, bisacurol, bisacurone, dan zingiberene) juga mengandung curcuminoids sebesar 1-2\% (Duke 2003). Warna kuning pada rhizoma Curcuma xanthorrhiza berhubungan dengan kandungan curcuminoids (Aggarwal et al. 2006) seperti halnya yang dimiliki oleh rhizoma Curcuma longa (Jurenka 2009). Walaupun demikian kandungan curcuminoid pada Curcuma longa lebih tinggi $(7,1 \%)$ dibandingkan dengan curcuminoids pada Curcuma xanthorrhiza (5,0\%) (Jantan et al. 2012). Hal tersebut mengakibatkan warna rhizoma Curcuma longa lebih kuning dibandingkan dengan warna rhizoma Curcuma xanthorrhiza. Selain curcuminoids, ternyata curcumin juga merupakan senyawa utama pada Curcuma domestica dan konsentrasinya sebesar $3,6 \%$, 
sedangkan pada Curcuma xanthorrhiza hanya 2,3\%. Hal yang sama juga pada jenis bisdemethoxycurcumin yaitu Curcuma domestica sebanyak 2,1\% sedangkan pada Curcuma xanthorrhiza hanya 0.8\% (Jantan et al. 2012).

Kandungan metabolit sekunder pada organ Curcuma xanthorrhiza bervariasi dalam jenis maupun kadarnya. Jantan et al. (2012) melaporkan jenis-jenis essensial oil yang ditemukan pada rhizoma Curcuma xanthorrhiza antara lain: $\alpha$ thujene, $\alpha$-pinene, camphene, $\beta$ pinene, cis-pinane, myrcene, $\alpha$ phellandrene, $\alpha$-terpinene, 1,8-cineole, (z)- $\beta$-ocimene, $\quad \gamma$-terpinene, $\quad 6,7$ epoxymyrcene, camphor, cis-dehydro$\beta$-terpineol, $\alpha$-terpineol, terpinen-4-ol, ethyl-4e-octenoate, dihydro citronellol acetate, $\quad \alpha$-cubebene, $\quad(z)-\beta$ damascenone, n-undecanol, geranyl acetate, $\beta$-cubebene, methyl perillate, (z)-isoeugenol, $\quad \alpha$-cis-bergamotene, methyl undecanoate, $\beta$-humulene, $(z)$ $\beta$-farnesene, $\quad \gamma$-elemene, $\quad(E)-\beta$ farnesene, $(E)$-ethyl cinnamate, arcurcumene, $\quad \gamma$-curcumene, $\beta$ bisabolene, $\quad(z)$ - $\gamma$-bisabolene, $\quad \beta$ curcumene, $\quad \beta$-sesquiphellandrene, 1,10-decanediol, $\quad(z)$-isoeugenol acetate, caryophyllene oxide, thujopsan-2- $\alpha$-ol, sesquithuriferol, 1,10-di-epi-cubenol, citronellyl pentanoate, cis-cadin-4-en-7-ol, cubenol, $\quad \alpha$-eudesmol, (e)-amyl cinnamic alcohol, (e)-citronellyl tiglate, $\beta$-bisabolol, ar-curcumen-15-al, 1 phenyl-hepta-1,3,5-triyne, 4-hydroxy-3methoxy-cinnamaldehyde, chamazulene, (e, z)-farnesol, $\alpha$ bisabolol oxide a, xanthorrhizol, butyl dodecanoate.

\section{Manfaat}

Curcuma xanthorrhiza telah dimanfaatkan sejak ratusan tahun lalu oleh manusia sebagai obat tradisional. Masyarakat lokal di Indonesia memanfaatkan Curcuma xanthorrhiza sebagai obat antara lain: obat maag (Silalahi et al. 2015a), diare, sakit perut, kurang giji, luka (Silalahi 2014). Pemanfaatan Curcuma xanthorrhiza sebagai obat tradisional berhubungan dengan bioaktivitasnya. Berbagai peneliti telah berhasil mengemukakan bioaktivitas Curcuma xanthorrhiza antara lain: anti-inflammatori, obat luka, menurunkan kolesterol serum darah (Beynen 1987: Dirsch et al. 1998), anti karsinogenik (Beynen 1987; Dirsch et al. 1998; Kim et al. 2014), antioxidan dan anti diabetik (Kim et al. 2014), antibakterial, antifungal, anticancer, phytoestrogenic, dan neuroprotective 
(Hwang et al. 2000; Lim et al. 2005), namun dalam artikel ini difokuskan pada pemanfaatan Curcuma xanthorrhiza sebagai anti mikroba (anti bakterial, anti fungal), antidiabetik, dan antioksidan. Pemanfaatan sebagai anti mikroba berhubungan dengan pemanfaatan sebagai pengawet makanan maupun sebagai obat diare.

\section{Anti mikroba}

Tumbuhan yang digunakan anti mikroba merupakan tumbuhan yang menghasilkan senyawa yang mampu menghambat pertumbuhan mikroba atau merusak komponen sel mikroba. Ekstrak Curcuma xanthorrhiza memiliki aktivitas sebagai anti bakteri (Lee et al., 2008; Mangunwardoyo et al. 2012; Anjusha dan Gangaprasad 2014), anti candida dan anti fungi (Rukayadi et al. 2006; Rukayadi dan Hwang, 2007). Kemampuan Curcuma xanthorrhiza untuk menghambat pertumbuhan mikroba berhubungan dengan pemanfaatannya sebagai obat maupun sebagai pengawet makanan.

$$
\text { Xanthorrhizol dari Curcuma }
$$
xanthorrhiza mampu menghambat pertumbuhan Bacillus cereus, Clostridium perfringens, Listeria monocytogenes, Staphylococcus aureus, Salmonella typhimurium, Vibrio parahaemolyticus (Lee et al. 2008), Klebsiella pneumoniae
(Anjusha and Gangaprasad 2014), Pseudomonas aeruginosa (Anjusha dan Gangaprasad 2014). Mikroba merupakan organisme yang mengakibatkan berbagai jenis penyakit pada manusia seperti diare atau gangguan saluran pencernaan pada manusia. Sebagian besar diare pada manusia disebabkan oleh kontaminasi mikroba pada makanan. Beberapa mikroba penyebab pembusukan makanan antara lain: Bacillus cereus, Clostridium perfringens, Listeria monocytogenes, Staphylococcus aureus, Salmonella typhimurium, dan Vibrio parahaemolyticus, sehingga sangat efektif digunakan sebagai pengawet makanan (Lee et al. 2008). Walaupun demikian namun xanthorrhizol tidak mampu menghambat pertumbuhan berbagai jenis bakteri seperti $C$. jejuni, Eschericia coli, S. sonnei, and $Y$. Enterocolitica (Lee et al. 2008), untuk itu diperlukan penelitian lebih lanjut untuk mengetahui efek dari xanthorrhiza pada konsentrasi yang lebih tinggi.

Hal yang berbeda ditemukan oleh (Lew et al. 2015) bahwa, pada konsentrasi xanthorhiza hingga $5 \%$ mampu menghambat pertumbuhan dan menginaktifkan bakteri Bacillus cereus, Escherichia coli, 
Pseudomonas spp. dan Staphylococcus aureus pada jamur (Pleurotus sajor-caju), sehingga sangat potensial digunakan sebagai sanitizer makanan. Untuk beberapa bakteri penyebab pembusukan makanan antara lain bakteri gram positive (B. cereus, $C$. perfringens, $L$. monocytogenes, $S$. aureus) dan bakteri gram-negative (Salmonella typhimurium and $V$. parahaemolyticus). Pemanfaatan Curcuma xanthorrhiza sebagai pengawet makanan alami memiliki kelebihan dibanding dengan pengawet sintetis karena tidak bersifat toksik. Ekstrak ethanol Curcuma xanthorrhiza menghambat pertumbuhan bakteri Gram positif Staphylococcus aureus dan S. mutans pada konsentrasi 1.0$5.0 \%(\mathrm{w} / \mathrm{v})$ (Mangunwardoyo et al. 2012),

\section{Antidiabetik}

Penelitian tumbuhan yang berpotensi sebagai anti diabetik semakin meningkat, hal tersebut berhubungan dengan makin meningkatnya penderita diabetes mellitus di dunia termasuk Indonesia. Berbagai masyarakat mengindentikkan penyakit diabetes mellitus berhubungan dengan kelebihan kadar gula di dalam tubuh, sehingga untuk menetralisasinya dibutuhkan tumbuhan yang secara empirik memiliki rasa pahit (Silalahi 2015a). Secara umum diketahui bahwa alkaloid dan tanin merupakan merupakan metabolit sekunder yang memiliki rasa pahit.

Terdapat dua jenis tipe penyakit dibaetes mellitus pada manusia yang disebut dengan tipe 1 dan tipe 2 . Diabetes mellitus tipe 2 berhubungan dengan obesitas. Obesitas menyebkan jaringan target resisten terhadap insulin (insulin-resistant) dan beresiko tinggi terhadap penyekit diabetes tipe 2 (Arcari et al. 2011; Vazquez-Prieto et al. 2012). Diabetes tipe 2 ditandai dengan peningkatan pelepasan asam lemak dari jaringan adiposa, penekanan penurunan output glukosa di hati, dan berkurangnya penyerapan glukosa yang diinduksi insulin pada otot (van Greevenbroek et al. 2013).

$$
\text { Wiryodidagdo }
$$

menyatakan bahwa tumbuhan utama berkhasiat sebagai obat penyakit diabetes mellitus merupakan tumbuhan yang menghasilkan senyawa yang mampu menekan atau merangsang kerja kelenjar endokrin, sehingga dapat memengaruhi produksi hormon dan mengubah proses fisiologi organ tubuh. Penelitian menunjukkan bahwa pemberian xanthorrhizol (10 atau $25 \mathrm{mg} / \mathrm{kg} /$ hari) atau ekstrak 
Curcuma xanthorrhiza (50 atau $100 \mathrm{mg} / \mathrm{kg} /$ hari) mampu menurunkan dengan cepat kadar glukosa darah secara signifikan pada tikus percobaan (Kim et al. 2015). Selain menurunkan kadar gula darah ternyata pemberian xanthorrhizol atau ekstrak Curcuma xanthorrhiza juga menurunkan insulin, glukosa, asam lemak bebas (free fatty acid), dan triglyceride di dalam serum (Kim et al. 2015).

\section{Antioksidan}

Antioksidan merupakan senyawa yang menghambat radikal bebas bebas di dalam tubuh. Senyawa yang berasal dari golongan fenolik lebih banyak dikenal sebagai antioksidan (Chan et al. 2007). Ekstrak methanol dari rhizoma Curcuma xanthorrhiza menunjukkan mampu menghambat aktivitas oksidasi coppermediated dari LDL (low density lipid). Ekstrak metanol dan etanol dari curcumin, demethoxycurcumin, bisdemethoxycurcumin rhizoma Curcuma xanthorrhiza menghambat probucol dengan nilai hingga (IC50 atau 0,57 $\mu \mathrm{mol} / \mathrm{L})$ (Jantan et al. 2012). Kandungan curcuminoids, xanthorrhizol, ar-turmerone dan zerumbone lebih tinggi jika diekstrak dengan methanol dibandingkan dengan etanol (Jantan et al. 2012). Kurkumin terbukti mengurangi kerusakan oksidatif dan defisit memori yang terkait dengan penuaan (Prasetya and Yuliani, 2014).

\section{KESIMPULAN}

1. Curcuma xanthorrhiza secara tradisional dimanfaatkan sebagai obat luka, maag, sakit perut dan juga sebagai pengawet makanan.

2. Xanthorhizol senyawa utama pada Curcuma xanthorrhiza yang memiliki bioaktivitas sebagai antimikroba, antioksidan dan antidiabetik.

\section{DAFTAR PUSTAKA}

Anjusha S. and Gangaprasad A. 2014. Phytochemical and Antibacterial Analysis of Two Important Curcuma species, Curcuma aromatica Salisb. and Curcuma xanthorrhiza Roxb. (Zingiberaceae), Journal of Pharmacognosy and Phytochemistry 3(3): 50-53.

Araújo, C.A.C., \& Leon, L.L. (2001). Biological activities of Curcuma longa L., Mem. Inst. Oswaldo Cruz, Rio de Janeiro 96(5): 723728.

Aggarwal, B.B., Bhatt, I.D., Ichikawa, H., Ahn, K.S., Sethi, G., Sandur, S.K., Natarajan, C., Seeram, N., Shishodia, S. (2006). Turmeric: the Genus Curcuma. Taylor and Francis, New York: 298-303.

Arcari, D.P., Bartchewsky, W., dos Santos, T.W., Oliveira, K.A., De 
Oliviera, C.C., Gotardo, E.M., Pedrazzoli, J.J., Gambero, A., Ferraz, L.F., Carvalho, P.O., Ribeiro, M.L., (2011). Anti inflammatory effects of yerba mat'e extract (Ilex paraguariensis) ameliorate insulin resistance in mice with high fat diet-induced obesity. Molecular and Cellular Endocrinology 335(2): 110-115.

Beynen, A.C. (1987). Lowering of serum cholesterol by Temoe Lawak singer, a curcuma mixture. Artery 14: 190-197.

Burkill, I.H. (1966). A Dictionary of Economic Products of the Malay Peninsula, vol. 1-2, Ministry of Agriculture and Co-operative, Kuala Lumpur, Malaysia.

Chan, E.W.C., Lim, Y.Y., \& Omar, M. (2007). Antioxidant and antibacterial activity of leaves of Etlingera species (Zingiberaceae) in Peninsular Malaysia. Food Chem 104: 1586-1593.

Devaraj, S., Esfahani, A.S., Ismail, S., Ramanathan, S., \& Yam, M.F. (2010). Evaluation of the antinociceptive activity and acute oral toxicity of standardized ethanolic extract of the rhizome of Curcuma xanthorrhiza Roxb. Molecules 15: 2925-2934

de Padua, L.S., Bunyapraphatsara, N. \& Lemmens, R.H.M.J. (Editors). (1999). Plant resources of SouthEast Asia No 12(1). Medicinal and Pousionous Plants 1. Backhuys Publishers, Leiden, the Netherland: $711 \mathrm{hlm}$.

Dirsch, V.M., Stuppner, H. \& Vollmar, A.M. (1998). The griess assay: suitable for a bio-guided fractionation of anti-inflammatory plant extracts. Planta Med. 64: 423-426.

Duke, J.A., Bogenschutz-Godwin, M.J., du Cellier, J. (2003). Handbook of Medicinal Spices. CRC Press, London: 150-152.

Helen, M.P.A., Gomathy, S.K., Jayasree, S., Nizzy, A.M., Rajagopal, B., \& Jeeva, S. (2012). Phytochemical characterization and antimicrobial activity of Curcuma xanthorrhiza Roxb. Asian Pacific Journal of Tropical Biomedicine 2(2): S637S640.

Hwang, J.K., Shim, J.S., Baek, N.I., \& Pyun, Y.R. (2000). Xanthorrhizol: a potential antibacterial agent from Curcuma xanthorrhiza against Streptococcus mutans. Planta Medica, 66(2): 196-197.

Jantan, I., Saputri, F.C., Qaisar, M.E., \& Buang, F. (2012). Correlation between Chemical Composition of Curcuma domestica and Curcuma xanthorrhiza and their antioxidant effect on human lowdensity lipoprotein oxidation. Evidence-Based Complementary and Alternative Medicine. 1-10. doi:10.1155/2012/438356.

Joy, P.P., Thomas, J., Mathew, S., \& Skaria, B.P. (1998). Medicinal Plants. Kerala: Kerala Agricultural University. $210 \mathrm{hlm}$.

Jurenka, J.S. (2009). Antiinflammatory properties of curcumin, a major constituent of Curcuma longa: A Review of Preclinical and Clinical Research Alternative. Medicine Review 14( 2): 141-153. 
Kim, M.B., Kim, C., Song, Y., \& Hwang, J.K. (2014). Antihyperglycemic and AntiInflammatory Effects of Standardized Curcuma xanthorrhiza Roxb. Extract and Its Active Compound Xanthorrhizol in High-Fat DietInduced Obese Mice. Hindawi Publishing Corporation EvidenceBased Complementary and Alternative Medicine, 10 pages http://dx.doi.org/10.1155/2014/20 5915

Larsen, K., \& Larsen, S.S. (2006). Gingers of Thailand, Queen Sirikit Botanic Garden, Chiang Mai.

Lawrence, G.H.M. (1951). Taxonomy of Vascular Plant. New York: John Wiley \& Sons

Lee, L.Y., Shim, J.S., Rukayadi, Y., \& Hwang, J.K. (2008). Antibacterial Activity of Xanthorrhizol Isolated from Curcuma xanthorrhiza Roxb. against Foodborne Pathogens, Journal of Food Protection 71(9): 1926-1930.

Lew, K.F., Goh, G.L., Son, R., \& Rukayadi, Y. (2015). Effect of Javanese turmeric (Curcuma xanthorrhiza Roxb.) extract on natural microflora of oyster mushroom (Pleurotus sajur-caju) and its sensory acceptability. International Food Research Journal 22(6): 2446-2451.

Lim, C.S., Jin, D.Q., Mok, H. Oh S.J., Lee J.U., Hwang, J.K., Ha, L., \& Han, J.S. (2005). Antioxidant and antiinflammatory activities of xanthorrhizol in hippocampal neurons and primary cultured microglia. Journal of
Neuroscience Research 82(6): 831-838.

Mangunwardoyo, W., Deasywaty, Usia, T. 2012. Antimicrobial and Identification Of Active Compound Curcuma xanthorrhiza Roxb. International Journal of Basic \& Applied Sciences 12(01): 69-78.

Munim, A. \& Hanani, E. (2011). Fisioterapi Dasar. Dian Rakyat. Jakarta: viii + 356hlm.

Prasetya, DY., S. Yuliani. 2014. Aktivitas Ekstrak Rimpang Temulawak (Curcuma xanthorrhiza Roxb.) Pada Radial Arm Maze Dan Pasive Avoidance Test Tikus Model Demensia. Pharmaçiana, 4(2): 157-164.

Rukayadi, Y., \& Hwang, J.K. (2006). Effect of coating the wells of a polystyrene microtiter plate with xanthorrhizol on the biofilm formation of Streptococcus mutans. J. Basic Microbiol. 46: 410-415.

Saensouk, P., Theerakulpisut, P., Thammathaworn, A., Saensouk, S., Maknoi, C., \& Kohkaew, P. (2015). Pollen morphology of genus Curcuma (Zingiberaceae) in Northeastern Thailand. Scienceasia 41: 1513-1874.

Srirugsa, P., Larsen, K., \& Maknoi, C. (2007). The Genus Curcuma L. (Zingiberaceae): distribution and classification with reference to species diversity in Thailand. Gardens Bulletin Singapore 59(1\&2): 203-220.

Skornickov, J., \& Sabu, M. (2005). The identity and distribution of Curcuma zanthorrhiza Roxb. 
(Zingiberaceae). Gardens' Bulletin Singapore 57: 199-210

Silalahi, M. (2014). The Ethnomedicine of The Medicinal Plants in Subethnic Batak North Sumatra and The Conservation Perspective. [Disertation]. Program Studi Biologi, Program Pasca Sarjana, FMIPA, Universitas Indonesia. [unpublished].

Silalahi, M., Nisyawati, Walujo, E.B., \& Supriatna, J. (2015a). Local knowledge of medicinal plants in sub-ethnic Batak Simalungun of North Sumatra, Indonesia, Biodiversitas 16(1): 44-54.

Silalahi, M, Nisyawati, Walujo, E.B., Supriatna, J. \& Mangunwardoyo, W. (2015b). The local knowledge of medicinal plants trader and diversity of medicinal plants in the Kabanjahe traditional market, North Sumatra, Indonesia. Journal Ethnopharmacology 175: 432-443.

Silalahi, M. (2017). Senyawa metabolit sekunder pada Etlingera elatior (Jack) R. M. Smith. Prosiding Seminar Nasional Pendidikan Biologi dan Sainteks, 20 Mei 2017. Universitas Muhamadiah Surakarta, Solo: 37-43.

Sylvester, W. S., Son, R., Lew, K. F. and Rukayadi, Y. 2015.
Antibacterial activity of Java turmeric (Curcuma xanthorrhiza Roxb.) extract against Klebsiella pneumoniae isolated from several vegetables, International Food Research Journal 22(5): 1770-1776.

Taiz, L., \& Zeiger, E. (2006). Plant Physiology. Sinauer Associates, Inc, Sunderland.

Vazquez-Prieto, M.A., Bettaieb, A., Haj, F.G., Fraga, \& Oteiza, P.I. (2012). (-)-Epicatechin prevents TNF $\alpha$-induced activation of signaling cascades involved in inflammation and insulin sensitivity in 3T3-L1 adipocytes. Archives of Biochemistry and Biophysics, 527 (2): 113-118.

van Greevenbroek, M.M.J., Schalkwijk, C.G. \& Stehouwer, C.D.A. (2013). Obesity-associated lowgrade inflammation in type 2 diabetes mellitus: causes and consequences, Netherlands Journal of Medicine 71(4): 174187.

Wiryowidagdo, S. (2000). Kimia dan farmakologi bahan alam Edisi I. Direktorat Pembinaan

Pengabdian Pada Masyarakat Direktorat Jenderal Pendidikan Tinggi Departemen Pendidikan Nasional. ix +325 